\title{
Crossing Borders Memories, Dreams, Fantasies, and Nightmares of the History Job Market
}

\section{Marc Stein}

In August 1998, I moved from the United States to Canada to begin my new job as a tenure-track assistant professor of US history at York University in Toronto. As a US citizen, I entered Canada on a temporary work permit but soon filed an application for permanent residency and landed immigrant status. In February 1999, I received a letter and a sealed envelope from Citizenship and Immigration Canada. The letter indicated that I needed to take the sealed envelope to the doctor who had conducted the medical examination that was a standard part of the permanent residency application process. Further tests were necessary, the letter informed me. When I called my doctor's office the next morning, I was given a same-day appointment. I asked on the telephone whether I was permitted to open the sealed envelope. The answer was no. Later that day, after the doctor opened the envelope and read the letter inside, he indicated that he was surprised. So sure was he, the doctor told me, that the additional tests would be psychiatric in nature (presumably because of gay-related information that I had supplied during my initial medical examination) that he had already started making telephone calls to find another doctor who could handle this type of case. But instead of requiring psychiatric tests, the letter indicated that an HIV test would be necessary.

I told the doctor that this is what I had suspected. Later I learned that until 1991 Canada officially regarded people with HIV/AIDS as a danger to public health and rejected most applications for permanent residency by people known to have HIV/AIDS. In 1991 a new policy was adopted that excluded most categories of people with HIV if they were expected to place an "excessive burden" on public health and social services. From 1991 to 2000 HIV antibody testing of permanent residency applicants was selective and could be ordered if the test seemed to be clinically indicated. In 2000 a new policy was announced under which HIV antibody testing for permanent residency applicants fifteen years of age or older became mandatory. Canada retained the "excessive burden" exclusion, which applied if the estimated financial burden was greater than that of the average Canadian, and interpreted this to require the exclusion of most people with HIV who were taking antiretroviral medications and most people with HIV in poor health. ${ }^{1}$

I did not tell the doctor that I had spent the day wondering whether I should refuse to consent to the test. It's not that I had much uncertainty about the results. I had been tested on three previous occasions and the results had been the same (negative) each time. I had not engaged in any unsafe sexual or

119

(c) Left History

9.2 (Spring/Summer 2004) 
intravenous needle practices since my last HIV test. While my aches and pains had increased that year, I suspected that this was more attributable to turning 35 than to anything more dire than that. But I had never had a non-confidential HIV test and the thought of having one gave me the creeps.

I have spent most of my life living in the United States, a country where the chances of obtaining health insurance after a non-confidential positive HIV test have often been as small as the chances of getting a same-day appointment with a doctor. Given the fact that most US Americans obtain health insurance through their places of work, this is a particularly significant problem for anyone with an erratic employment history, which was certainly the case for me after I began graduate school in 1989. Most of my friends have had HIV tests at one time or another; none, as far as I know, has ever had it done non-confidentially.

Moreover, once upon a time in the late 1980 s, at a very different moment in the AIDS crisis, I had written a column titled, "Why I Choose Not To Be HIV Tested" for Gay Community News, the Boston-based lesbian and gay newspaper that I edited before I began graduate school. While times had certainly changed and I would not take this position today (most significantly, there are now more effective medical interventions than there were in 1988), some of the political concerns that motivated the position that I took in 1988, concerns related to confidentiality, insurance, and access to health care, remained alive and well in 1999.

I was troubled also because I resented the implication that if I were HIV positive I would not be granted permanent residency. It's not that I failed to understand the reluctance of the Canadian government to assume the healthrelated costs of a US American who entered the country with HIV, particularly when the United States required HIV tests for everyone applying for permanent residency and particularly when the US health care system was (and is) so incredibly retrograde. It's not that I was not grateful that York was willing to hire a US American when US schools so rarely hire Canadians (particularly in a field like history, where US departments almost never hire scholars who specialize in Canadian history). But recognizing the realities of national borders did not lessen my resentment as a global citizen.

I also resented the fact that something in my permanent residency application or my initial medical examination apparently had placed me in a suspect class. Could it have been the many organizational memberships that I was required to list that included the words lesbian, gay, or AIDS? Could it have been the minor medical problems (some of which are often associated with gay men) that I had reported? Whatever had placed me in this suspect class presumably made all sorts of assumptions about these organizations and these problems and simultaneously made all sorts of assumptions about the non-suspect nature of other classes of applicants, assumptions that on a global level 
continue to threaten millions of lives.

Most of all, after a five-year academic job search that involved approximately 150 applications, 25 interviews, four offers of one-year positions, and three temporary jobs in two US states, a job search that only ended after I decided to migrate transnationally, I resented the fact that I might lose my semi-secure employment. It may seem to some that I would have had greater things to worry about if I had tested HIV positive than losing a semi-secure job, but I am not so sure about that. Given relatively long life-expectancies and high health care costs for people who are HIV positive, losing semi-secure employment would certainly rank up there as a source of anxiety if I ever tested positive.

In any case, there was another reason, admittedly more perverse, that led me to think about refusing to take the HIV test. I knew that the story of refusing, being denied permanent residency, and losing my tenure-track job at York as a result would make a great introduction to my second book. That book, tentatively titled The US Supreme Court's Sexual Revolution?, will feature an analysis of a 1967 ruling, Boutilier $v$. the Immigration and Naturalization Service. In this case, the US Supreme Court decided that the United States could deport a Canadian gay man because his character and conduct as a "homosexual" made him excludable under the psychopathic personality provisions of US immigration statutes. ${ }^{2}$ Making the story even better, this is the case that formed the basis of the lecture that I gave during my job interview at York. What better way to begin my next book, I found myself thinking, than to tell the story of my being excluded from Canada more than 30 years after Boutilier was ruled excludable from the United States. It did not matter that I possibly could have continued working at York on a temporary work permit; just the thought of being able to use this melodramatic story tempted me.

Months before this thought occurred to me, a comparably perverse one had come to mind. One of the things required as part of my permanent residency application was a letter from the US Federal Bureau of Investigation indicating whether I had a police record in the United States. I had waited anxiously for this letter, not sure about what the FBI would say. In 1987, I participated in one of the largest civil disobedience actions ever organized in the United States. Along with hundreds of others, I tried nonviolently to gain access to the US Supreme Court building in Washington, DC, after the Court issued its infamous ruling in Bowers v. Hardwick, a 1986 decision that upheld state sodomy laws. I remember many things about that day in the US capital. I remember the yellow gloves that the police wore to protect themselves from contagious elements. In fact I still have the parodic yellow gloves that we wore, complete with purple nail polish on each fingertip. I remember running toward the building with a group of friends; being stopped by police; sitting down and locking arms; and getting up and making a second run after the police had moved on to 


\section{Stein}

deal with other protestors. I remember that the police then ushered my affinity group onto buses, took us to a school gymnasium, and required that we pay fines to be released. I actually remember it as one of the proudest days of my life. But I do not remember whether, technically speaking, I was arrested. Years later, when the FBI letter arrived with a stamp that indicated that I did not have a police record, I was both relieved and disappointed: relieved because I would not have this particular problem with my residency application, disappointed because something that was a source of pride to me (and that could also have been used in my book's introduction) had been diminished by not showing up in the FBI's files.

In the end, I went ahead with the HIV test, waited two weeks, and then got the same results that I had gotten the other three times that I had been tested. And within a few months, I was a permanent resident of Canada.

Years later, I still wonder why I consented to the HIV test. I think it was a sign of many things. Maybe I did not have time to think through my choices. Maybe I had grown more conservative. Maybe I thought that I had a great deal to lose. Maybe I felt more vulnerable to state authority in a country where I am not a citizen. Maybe the ex-patriot expatriate in me thought that Canada's more advanced health care system should not have to take care of those who would not be cared for in the United States. Maybe I wanted to confirm my HIV status. Maybe I felt that there were other ways that I could express my solidarity with people who are HIV positive and people who have AIDS. Maybe that's why I am sharing this story now.

One point that this story illustrates is that when it comes to the academic job market, "it ain't over" even when it seems to be over. But this story also illustrates the main point that I want to make in this essay - that understanding the academic job search process cannot be isolated from understanding the politics of identity and the political economies that operate within our societies and cultures today. Over the course of my five years on the history job market, I promised myself hundreds of times that if and when I achieved semi-secure employment, I would write and speak about my experiences as one small way of contributing to change. Now that I am tenured and can take greater advantage of so-called "academic freedom," I hope you will indulge me as I review these years.

\section{Year one (1993-94)}

I am in my fifth year of graduate studies at the University of Pennsylvania and decide to take my first shot at the history job market. Drawn back to school in the late 1980s in part by reports about the impending national shortage of academics, I have since learned that more than 50 percent of college and university courses in the United States are now being taught by part-time and tempo- 
rary teachers. The general job outlook is bleak and I have told myself many times that doing a lesbian and gay history dissertation might doom my chances. Despite all of this, I have trouble controlling my hopefulness. I have done well in my graduate classes, have taught general survey courses in US history, have received excellent student evaluations, and have been elected president of my University's Graduate History Association. I have also begun to give several conference papers a year, have an article coming out in a good journal (Radical History Review), have an impressive set of advisors (Carroll Smith-Rosenberg, Michael Katz, and Mary Frances Berry) in a good graduate program, and have made substantial progress on my dissertation, which focuses on the history of relations between lesbians and gay men in Philadelphia from the 1940s to the 1970s. In fact, I have won the first graduate fellowship in lesbian and gay history offered in the United States (the Ken Dawson Award, given by the Center for Lesbian and Gay Studies at the City University of New York Graduate Center), as well as Mellon fellowships offered by Penn. In my work, I am making strong efforts to link my case study in lesbian and gay history to so-called "larger" themes in social, cultural, political, and urban history, as well as the history of sex, gender, and sexuality. I am on my way to becoming one of the first ten people to complete a $\mathrm{PhD}$ dissertation that focuses primarily on US lesbian and gay history. ${ }^{3}$ Three of my most accomplished predecessors (John D'Emilio, George Chauncey, and Lisa Duggan), all very talented, have each taken three or more years to get tenure-track jobs and I figure that I had better start the process sooner rather than later. ${ }^{4}$

I apply to about 40 jobs in various fields, mostly in twentieth century US history, post-1865 US history, and US political, social, cultural, urban, and women's history. Of all of the fields covered by history departments in the United States, twentieth century US history has the most job openings and the most job applicants. There are no listings in lesbian and gay history or the history of sexuality. While I only apply to jobs in the United States, I otherwise do not restrict myself in terms of location, quality of school, or teaching load. In most cases, I am competing with about 200 applicants, although in some cases the number is more like 100 and in others it is as high as 500 .

My advisors and I are very pleased with the set of American Historical Association (AHA) convention interviews that I obtain. Most history departments in the United States interview ten to fifteen candidates at the AHA convention in January and then invite two to four finalists for campus interviews. Of the AHA interviews that I am offered in my first year on the job market, the most exciting to me are with the University of Massachusetts at Amherst and the College of William and Mary, but I am also pleased to be interviewing with Florida International University and Virginia Commonwealth University. At the convention itself, I am offered a last-minute interview with the University of Northern Colorado. As I prepare for the interviews, I spend more than a 
thousand US dollars (more than the monthly stipend that I receive as a teaching assistant) on the suits, ties, dress shirts, and long winter coat that I need. I take advantage of the practice interviews that my department schedules, which are very helpful (particularly for improving my answer to the question of why I would want to live in Williamsburg, Virginia). I also talk with my dissertation supervisor (Smith-Rosenberg) about my glasses, which I fear are too eccentrically stylish for conservative historians, my two earrings, which are not particularly stylish but which I fear may still freak out historians, and my hair, which is long enough to wear in a ponytail. She tells me to cut the hair, but says that I should not sacrifice all sense of style for the profession and encourages me to keep the earrings and glasses. Of course we also talk about matters of substance.

The interviews with UMass, William and Mary, and Florida International go well. Logistically confusing instructions involving two hotel rooms lead me to the wrong place for my interview with Virginia Commonwealth; by the time I figure out the mistake I am quite late and the interview suffers as a result. In one or two of the interviews, I get the distinct feeling that I am being considered only so that the department or search committee can congratulate itself on being open-minded enough to interview a candidate working on lesbian and gay history. My first overtly troubling moment comes when the interviewer from Northern Colorado asks me why I think my subject of research is best studied in history as opposed to psychology or anthropology. As I answer respectfully, discussing the roots of lesbian and gay studies in the disciplines of psychology and medicine, I say to myself that if these types of questions continue I will have to walk out or be confrontational. Florida International asks me the same question, but prefaces it more carefully by indicating that the committee is interested in hearing how I would answer such a question if someone ever posed it to me (as if the questioner has not just posed it). Later I am told that I did well enough with William and Mary and Florida International to make me an alternate for campus interviews. William and Mary hires a historian whose dissertation includes substantial lesbian content and Florida International hires one of my closest friends at Penn. I learn later that a senior member of the department at Florida International argues that my research is "politics, not history," and that this damages my chances there insofar as there are no comparable objections to my highly qualified friend from Penn. This will not be the only time in a highly competitive job market when one faculty member's objection dooms my candidacy. ${ }^{5}$

UMass invites me, along with three other candidates, to campus. In planning for the interview, I think about whether, if asked in the informal conversations that invariably take place during campus visits, I should reveal the fact that I have had a girlfriend for two years. I fear that either this will confuse the department because of assumptions made about who does lesbian and gay his- 
tory, why we do it, and what it means to be lesbian or gay, or that I will lose the support of those who want to hire me precisely because they assume that I am gay and that they know what this means. In the end, although a member of the search committee initiates with me a very personal discussion about the sexual assumptions that are often made about a straight son's intimate friendship with a man who had recently died (I knew both the son and the friend as acquaintances when we all were undergraduate students at the same university), I manage to avoid the subject of my relationships. I enjoy my time at UMass and leave with high hopes. When the bad news comes, it is not entirely depressing. I rank third out of four; I am considered strong enough so that if the first two candidates turn down the job it will be offered to me; and I am told that the two candidates ranked ahead of me have finished dissertations and several years of full-time teaching behind them. Several weeks later, I check in with the chair of the search committee and learn that the first candidate has turned down the job. The chair expects the second candidate to accept the offer but cannot be sure. That's the last I hear from UMass. Years later a friend and I are talking about the many places that interviewed us but never sent official rejection letters. I joke that maybe I should write to UMass and say that after years of waiting I need to have an answer so that I can consider my other options. Meanwhile, my first year's search is over. Several of my classmates have gotten tenure-track jobs; I am very happy for them but it's hard not to feel envious. Penn offers me a position teaching three courses for the following year and I get back to work on my dissertation.

\section{Year two (1994-95)}

After the close calls with UMass, Florida International, and William and Mary, I decide that to strengthen my marketability I should finish my dissertation and teach more courses. The dissertation is done and accepted by the end of 1994 . While dissertation writing is not a race, I am pleased to be the second person in my class to finish my degree. I add courses in US women's history and the history of sexuality to my teaching portfolio. I also decide that since eight publishers have approached me about signing a book contract, I should pursue this. There is something unreal about this, but other lesbian and gay historians have told me that while we are all experiencing difficulties obtaining tenure-track jobs, publishers have recognized what history departments have not - that there is substantial public interest in (and a substantial market for) our work. And sure enough, editors begin to court me, taking me out for lunches and dinners and even travelling to Philadelphia to try to clinch deals. Martin Duberman, probably the most well-known gay historian in the United States, offers to put in a good word with his New York literary agent and she agrees to take me on as a client. This is definitely unreal. My agent negotiates for me a good book deal with the University of Chicago Press that not only will place my book in 


\section{Stein}

a great series and guarantee me money and space for dozens of illustrations, but will also provide me with a royalties advance (enough to support me for a summer) and the means to do a small publicity tour when the book comes out. In the fall of 1994, I sign the contract, teach a full course load for the first time, finish my dissertation, and watch my relationship break up. Mourning the end of the relationship, I tell myself that at least I will not have to worry about how to avoid mentioning my girlfriend in my interviews.

I again apply to about 40 jobs and the results are strikingly different from those of my first year. I am offered only two AHA convention interviews - with Xavier University (a Catholic institution in Cincinnati) and the College of Staten Island. At the convention, I also am offered an interview with Bemidji State in northern Minnesota. Although I am told that it's futile to figure out why the job market works the way that it does, it seems telling that the jobs at Xavier and Staten Island are in women's history (whereas in the previous year I had no interviews in this field). I look back at my letters of application and see that this year I highlighted the fact that I am currently teaching women's history at Penn. I suspect that because I identified myself as a women's historian, I hurt my chances for other positions. At the convention, during one of my interviews, the chair of the search committee informs me, quite out of the blue, that $\mathrm{s} / \mathrm{he}$ is gay. I wonder whether this is why I am being interviewed and how I am supposed to respond, but we quickly move on to other topics. Although I learn later that I am an alternate for a campus interview at Xavier, none of the schools ends up bringing me to campus.

Fortunately, I have applied for several postdoctoral fellowships. Friends have told me that fellowship-granting agencies, like publishers, have identified lesbian and gay studies as an area that they would like to cultivate. In fact at one point Philadelphia alone is home to five postdoctoral fellows in lesbian and gay studies. Across many humanities and social science disciplines, lesbian and gay studies scholars are winning postdoctoral fellowships and one-year faculty positions but not longer-term ones. Cynics conclude that departments like to have us around to spice things up and increase course enrollments but do not want to commit to working with us on a more long-term basis. In any case, I am tremendously relieved when I win two fellowships, one at Ohio State University, which I decline, and one at Bryn Mawr College, which I accept. In both cases, lesbian historians who specialize in the history of sexuality play prominent roles in my selection. In the spring of 1995, despite the job market problems, I am pleased to be graduating and moving on to Bryn Mawr and I am happy that several more of my classmates have gotten tenure-track jobs. My spirits are further lifted when Lingua Franca features me in an article called "Robbing the Cradle," which focuses on the new phenomenon of publishers pursuing book contracts with graduate students who have not finished their dissertations. ${ }^{6}$ Maybe, I figure, this kind of media attention will help my 
job market chances.

On the down side, I have a disturbing encounter with another student in my graduate program, who, like me, has not obtained a tenure-track job. In passing, he says to me that he guesses that we must be of the wrong sex and race to get jobs these days. I am offended on many levels. First, his situation and mine are not comparable since he is not dealing with historically powerful prejudices against his identities and research interests. Second, what he says is inaccurate; AHA statistics demonstrate clearly that the majority of jobs in history in the United States continue to go to Euro-American men. And third, as a long-time supporter of programs to increase the abysmal representation of women and people of color in history departments, I find what he says reprehensible. I challenge him, but not nearly as strongly as I should, and I worry about whether my job market troubles are poisoning my politics.

\section{Year three (1995-96)}

As a postdoctoral fellow at Bryn Mawr, I am teaching fourth-year seminars in urban history and social movement history. I embark on new research to strengthen my manuscript until November arrives, when it's time to turn my attention again to the job season. By this time, I have a second article accepted for publication (in a Routledge anthology) and am beginning to speak not only as a panelist at several conferences a year but also as an invited guest lecturer at such schools as the University of Chicago and Johns Hopkins University. I have also purchased more conservative glasses. After applying again for approximately 40 jobs, I obtain my best set of AHA convention interviews. The jackpot is an interview for a tenure-track job at the University of California, Berkeley, but I am also very pleased about interviews for a tenure-track job at the University of Miami and shorter-term positions at Duke University and Colby College. The interviews with Berkeley, Miami, and Colby go well. (With Duke, I find it difficult to navigate through what appears to be a major conflict between search committee members, one of whom seems to object to me primarily because someone else on the committee seems to support me.) Shortly after the convention, Berkeley and Colby invite me to campus. Miami, whose position is in urban history, does not. Later I learn that I am one of three alternates for a campus interview there and that the two candidates brought to campus are considered stronger because they do "just urban history" whereas the three alternates do urban history as well as things like race, gender, and sexuality. I joke to friends about the new field of "just urban history" and the new Journal of Just Urban History, a journal that must include only narrowly conceived essays on architectural and environmental history since all work that directly involves people is apparently excluded.

The campus interview at Colby goes well. The job is a one-year sabbatical 
replacement for a US women's historian. Within days, Colby offers me the position. Unfortunately, however, Colby gives me a deadline that will coincide with my campus interview at Berkeley. Further complicating matters is the fact that on my first evening at Berkeley, I call home and learn that I have been offered a campus interview for another position. For what I believe is the second time in the United States ever, there has been a job advertised in lesbian and gay studies for which historians will be considered. The job is at Emory University.

Now I have a difficult situation to negotiate. Having been told that there's nothing more likely to increase one's academic desirability than to announce that another department finds one desirable (a phenomenon that it's easy for a historian of sexuality to recognize), I decide to speak to the chair at Berkeley, reveal my offer of a non-tenure-track job at Colby, and make clear that I will turn down the job offer at Colby if accepting it will jeopardize my chances at Berkeley. The chair tells me that Colby is behaving badly by imposing a deadline for a one-year job offer in the midst of the tenure-track job season. There are hints that Berkeley will not object if I accept Colby's offer and then either defer beginning at Berkeley for a year or find a way out of my Colby contract. Meanwhile, all of this is hypothetical since I have not been offered a position by Berkeley, which is interviewing five candidates. My interview goes well, though two troubling incidents stand out. One is with a member of the department who asks me about the courses that I have taught at Bryn Mawr. When I describe my social movements course, mentioning at first that we cover African American, women's, and lesbian/gay movements in the first threequarters of the course, this professor interrupts and asks why I do not consider movements from the other side of the political spectrum. I finish my sentence by describing the conservative movements that I teach in the last quarter.

Far more disturbing is what happens during the research lecture that I have been asked to deliver. I have been told by multiple sources that several prominent members of the Berkeley department are very supportive of my candidacy. Partly because of this, the audience for my lecture is so large that the room has to be changed at the last minute to accommodate everyone. After I conclude my lecture, the first hand to go up belongs to a member of the department who, I have been told, is the one member of the search committee who has problems with my candidacy. The question this person asks is whether my research deals at all with pedophilia. As my stomach turns over, I pretend to have not heard the question and ask her to repeat it. On the one hand, this professor is writing a book on a related topic and can claim a personal interest in the subject. On the other hand, I have not talked about pedophilia at all, have not thought about it in relation to my work, and take the question for what it is - an inflammatory and horrific question that presumes links between lesbian and gay history and the history of pedophilia. This has been a favored rhetor- 
ical strategy used by social conservatives to attack lesbian and gay phenomena for decades. Although parallels like the one I am about to make are often dangerous and misguided, the question seems akin to asking an African American historian who has lectured about the history of slavery to comment on the subject of black men raping white women. Responding to the question as best I can, I first, without knowing where I am going, draw a political and ethical distinction between "pedophilia" involving post-pubescent youth and "pedophilia" involving pre-pubescent youth. Having set up this framework, I then figure out where to go: I say that the more moderate gay activists discussed in my lecture imposed age restrictions of eighteen on their memberships while the more radical activists, also discussed in my lecture, welcomed post-pubescent minors into their organizations. The remainder of the questions passes in a blur and I am soon back in Philadelphia. The interview for the lesbian and gay studies job at Emory goes well and now I await news.

Impatient about its one-year position, Colby demands an answer. I solicit advice from many quarters about what to do. In particular, I go to one of my teachers at Penn, who is known for offering the following comment when graduate students have confronted similar situations in the past: "Slavery was abolished in the United States in 1865." Sure enough that's precisely what this teacher says to me. After receiving advice from about a dozen professors, I accept Colby's job orally, though delay accepting in writing. Meanwhile, Berkeley calls to let me know that one candidate has been ruled out, four are still in the running, and the department would now like to see my entire manuscript. A short time later, Berkeley calls to say that another candidate has been ruled out and the department now would like to see the readers' reports submitted to my publisher. More time goes by and Berkeley calls to say that there are now two remaining finalists and the department would like the names of four scholars not affiliated with my graduate program who can comment on my work. No one I know has ever heard about a process like this for a junior hire.

Soon I find out that I have placed second for Emory's job. That position has been offered to a well-known sociologist who is an assistant professor elsewhere and has published two influential books on AIDS. While I hear that the sociologist is asking to be given the job with tenure, in the end this person accepts it without. Meanwhile, when the news comes from Berkeley I am devastated. The other candidate is chosen. I hear later that the dean at Berkeley had indicated that if there was overwhelming sentiment for a second candidate then the department could offer positions to both of us. I hear that I received a majority, but not an overwhelming majority, of votes for a second position. I also am told (without clarifying details) that things were said in departmental meetings at Berkeley that provide grounds for me to file a discrimination suit, but I choose not to pursue this. I have a difficult time getting over Berkeley's rejection, particularly because members of the department begin referring 
undergraduate and graduate students to me for assistance, since no one in the department is an expert in US lesbian and gay history. I help the students but privately award Berkeley with the tackiest post-search behavior prize. Notwithstanding all of this, I try to remember that I do have a good job, if a short-term one, at Colby. In the summer of 1996, I leave Philadelphia and move to rural Maine, going into what I melodramatically call "exile." I have never, as an adult, lived outside of a large metropolitan area, and the only person I know in the entire state of Maine is an ex-lover who lives 90 minutes away from Waterville, where Colby is located. Soon after arriving in Maine, I meet another exile, a Cuban American man who teaches at Colby, and we become involved. Friends tell me that it's now clear that there was "a reason" that I did not get the other jobs. This annoys me to no end but I enjoy my new role as poster-boy for single faculty who move from big cities to rural regions and find love, and I am happy beyond words for my life's surprising new direction.

\section{Year four (1996-97)}

In the fall of 1996, my partner and I decide that I should approach my chair and dean to let them know that I am interested in remaining at Colby should a position become available. With evidence that my teaching and research are strong and deal with subjects not otherwise covered by the college faculty, and with knowledge that I have a partner who is a respected and well-liked full professor with an endowed chair and who chairs the Spanish Department and the Latin American Studies Program, Colby should have various reasons to try to keep me. By November, I have an offer for a second one-year position at Colby and several months to give my response. With an offer that will keep me working for the next eighteen months, this is the most job security that I have had since beginning graduate school in 1989. Meanwhile, I become active in the revival of a Colby chapter of the American Association of University Professors (AAUP), which quickly becomes a leading advocate for faculty interests. As a United Parcel Service strike focusing on part-time and temporary work issues disrupts business as usual on campus, I encourage our AAUP chapter to focus attention on the problems of part-time and temporary faculty, including inadequate office space, disenfranchisement in college governance, and ambiguous and discriminatory policies concerning grants and benefits.

While this is happening, I apply again for jobs, this time pursuing only tenure-track positions and only positions that seem particularly attractive. Instead of applying for 40 jobs, I apply for 25 . Five schools offer me AHA convention interviews. I am most excited about the University of Oregon, but also have interviews with the University of South Florida, the University of Alabama-Birmingham, Depaul University, and Eastern Connecticut State University. All of the interviews seem to go well. I learn later that I am an alter- 
nate for a campus interview at Oregon. South Florida and AlabamaBirmingham invite me to campus shortly after the convention.

Hoping to minimize the disruption to my teaching, I schedule these interviews back-to-back during Colby's one-week break between its January and spring terms. I prepare for these interviews with feelings of dread, ambivalent about getting a job that will force me to leave my partner in. Maine and not particularly excited about these schools after close calls with UMass, Berkeley, and Emory. A week before I leave for South Florida, my neck pretty much stops rotating but several days later it regains mobility. I arrive in Tampa in the evening and go directly to my hotel. In the middle of the night I wake up soaking wet. Thinking that I must be anxious or that I must be having trouble adjusting to Florida's warm climate, I change my clothes and go back to sleep. An hour later, I am soaking wet again. As it turns out, I have the worst flu of my life. The South Florida interview is a blur, but incredibly I learn later that I somehow did well enough to place second out of three for this job. Then I fly to Boston for a night, a ridiculous detour on my way from Alabama to Florida but one made necessary by what I am told is the need to avoid revealing information about other interviews to schools that are interested in me. I consider cancelling the Birmingham interview but in the end decide to go ahead with it. By the time my lecture arrives, I can barely speak and need to sip water after each sentence of my presentation. I am so out of it that I do not realize what members of the department apologetically tell me later: that one of their senior colleagues, hostile to the idea of hiring someone who does lesbian and gay history, reads his mail and journals during my lecture. Several weeks after I return to Colby, Eastern Connecticut offers me a campus interview but its process will take months and will require the active approval of the search committee, the department, the dean, and the president. Meanwhile, Colby wants an answer, which I provide in the affirmative.

\section{Year five (1997-98)}

I have moved in with my partner. I have won a "best dissertation chapter" award. I have spent thousands of dollars on travel and accommodations related to interviewing. I have lost what I estimate to be about a year's work on my book because of the demands of applying, interviewing, and moving for jobs, but the book is now nearly finished. I have given 20 conference papers and have given invited lectures at, among other institutions, Harvard and Wesleyan. I begin to joke that I have given so many talks and have interviewed for so many jobs that I have hurt the market for my book. I am serving on the boards of two history journals. My job applications have been strong enough to get me multiple AHA convention interviews; my convention interviews have been strong enough to get me multiple campus interviews; and my campus inter- 
views have been strong enough to get me multiple postdoctoral fellowships and one-year positions. Everyone in my graduate cohort at Penn who has finished a dissertation and done a national job search has been hired for a tenure-track job; several are already going through the standard six-semester review that is the first step toward tenure in many US schools. They express outrage at my job problems, but I begin to fear that this is just because they are my friends. I have been living what has felt like a temporary life for nine years. I have had enough.

I joke about becoming a traditional faculty spouse in the United States, taking French classes, teaching piano, and hosting teas. I think that maybe Colby will offer me occasional courses. I begin to look into alternative careers in publishing, journalism, and non-profit management. I fantasize that since my first book contract supported me for a few months, perhaps a second could support me for a longer period of time. Fearing unemployment, I have not spent much of the money that I have earned while living in the low-cost state of Maine and I figure that I can live on my savings for a year while I plan a new career.

There are now (in 1997-98) more than 30 people who have finished dissertations that are fully or partially about US lesbian, gay, bisexual, transgender, or queer (LGBTQ) history. Of those who have completed history dissertations that are primarily LGBTQ in content, I know of only three who have been hired in tenure-track positions by US history departments. Of the remainder, I am one of the lucky ones, with an Ivy League degree, various convention and campus interviews, and various temporary and part-time job offers. I sense that the dozen or so graduate students who are writing dissertations on LGBTQ history are anxiously watching those of us who have finished our degrees to see what they can expect and to see with whom they might be competing down the road. I fear that I am letting them down.

After the experiences with South Florida and Alabama, where my ambivalences probably contributed to my illness, I decide that I will only apply to jobs about which I can be genuinely enthusiastic. I am outraged when several fellowship advertisements indicate that I am ineligible because my $1994 \mathrm{PhD}$ is now too old. In all, I apply for only six positions, including York's. I plan to go to the AHA convention in Seattle but cancel after I obtain no interviews. Soon thereafter, Colby offers me another one-year position but I am not sure that it will be good for me to accept and continue living a temporary life. As Colby's deadline approaches, York calls to offer an interview. By this time, campus interviews have become routine and I do not prepare for the interview very aggressively. To demonstrate that I am an experienced and successful teacher, I make sure to supply York with copies of recent teaching evaluations and a dozen syllabi that I have prepared over the years. To present myself as an accomplished and advanced scholar, I lecture about my new work on Boutilier 
$v$ the Immigration and Naturalization Service, rather than my older work on Philadelphia lesbian and gay history. (This has the added advantage of featuring a slice of US history that relates directly to Canada.) The campus visit goes well, I think, but then again I have thought the same thing about most of the others. During the day that I spend in Toronto, half a dozen members of the department tell me, one at a time, that York prohibits faculty from asking prospective job candidates about their personal lives. The question is repeated so often that I begin to assume that it betrays great interest in the subject, so I decide to volunteer information about my relationship over dinner. I figure that withholding personal information has not worked in previous interviews so perhaps volunteering it will help me here. I also think to myself that, to the extent that gay men are sometimes seen as "dangerous" teachers of young male students, perhaps mentioning my stable relationship with a man a few years older than I will make me seem less threatening. In any case, after the interview I return home and wait impatiently for York to turn me down. Meanwhile, Yale calls to say that I am an alternate for a one-year position in lesbian and gay studies, Bates offers me an interview for a visiting position, and Colby sets a firm deadline for me to accept its offer. After the good news comes from York, I put down the telephone and cry.

Undoubtedly concerned about retaining my partner and apparently pleased with my work, Colby indicates that it may be able to offer me a two-year position instead of a one-year one but I make clear that this will not be enough to keep me. Around this time, Maine holds a referendum that, for the first time anywhere in the United States, overturns a state statute that prohibits discrimination on the basis of sexual orientation. Canada, I soon learn, officially prohibits this type of discrimination everywhere, at least for its citizens. Soon I learn that a friend with a completed dissertation on US lesbian and gay history, who has also been looking for a tenure-track position, has been hired in a tenure-track equivalent position by the University of York, but his York is in England. We joke that the United States is exporting PhD's in lesbian and gay history as fast as it produces us. When mutual friends mistakenly express surprise that York has hired two gay historians, I allow myself to fantasize that perhaps my York will not treat me as a token and will consider hiring other historians of sexuality. My decision is not a difficult one. I am excited about living in multicultural and dynamic Toronto, about working at an institution with graduate students, and about being part of an intellectually serious and politically progressive department. I accept York's offer and believe that my job search is over.

At Colby, I was wary of becoming the poster-boy for single academics who move to Maine (or similar types of places) and find love. At York, I am wary of becoming the poster-boy for perseverance on the academic job market. According to a survey I completed in 2000 as chair of the Committee on 
Lesbian and Gay History, an affiliated society of the AHA, of 32 respondents who had completed $\mathrm{PhD}$ dissertations on LGBTQ history in graduate programs in the United States and Canada, only eighteen had secured tenure-track or equivalent positions. The other fourteen were working in part-time or temporary academic positions, in educational administration, in libraries and archives, in public history, or in other non-academic jobs. A majority of the eighteen tenure-track or equivalent positions were in history departments outside of the United States, in women's studies/gender studies unit, in American Studies units, or in other non-history units. Of the eight tenure-track or equivalent respondents who had exclusive appointments in US history departments, two did dissertations described as 100 percent LGBTQ in contents; the other six did dissertations described as 10-30 percent LGBTQ in contents. Thus, with only two exceptions, respondents who completed history dissertations that were more than one-third LGBTQ in contents were not employed in tenuretrack or equivalent positions in which US history departments acted as the primary hiring units. ${ }^{7}$ In other words, I consider myself very fortunate and the general situation remains bleak.

We each have to make very personal decisions about how much of the horrors of academic job searches we want to put ourselves through. We each have to make very personal decisions about when enough is enough. But I do think that there are several collective things, beyond the activities of the Committee on Lesbian and Gay History and the Canadian Committee on the History of Sexuality, that can be done to deal with some of the problems described here.

First, those concerned about the future of academic LGBTQ history can be more open and communicative about job searches, share information about how they work, demystify the process, train graduate students on matters of style and substance, lend support and provide information to job applicants, and hold departments accountable for their practices. At all times we should remember that confidentiality is a policy adopted by search committees, programs, and departments, not by job candidates.

Second, we can encourage academic search committees, departments, schools, and professional associations to develop more creative and more aggressive anti-discrimination and affirmative action programs. Colleges and universities are not doing a good enough job in this area and they need to do more if we are going to promote excellence in education. While hiring LGBTQ historians should certainly not be equated with hiring historians who themselves identify as LGBTQ, movement on the latter could help movement on the former, and vice versa. Those of us who are advantaged in terms of ability, class, ethnicity, gender, language, race, religion, sex, and sexuality can acknowledge these advantages, not allow localized and personalized exceptions to mislead us about general patterns, and lend our support to anti-discrimination and affirmative action struggles, even when they seem to work 
against our personal interests.

Third, we can build alliances, in and beyond job market contexts, between different communities of academics concerned about boundaries and hierarchies of ability, class, ethnicity, gender, language, race, religion, sex, and sexuality. When I review the interviews that I have had, I see a majority of search committees chaired by women, women's historians, African Americans, and/or African American historians. I do not think that this is an accident. And LGBTQ historians can build productive alliances with LGBTQ scholars in other disciplines.

Fourth, we can encourage history departments to be more imaginative with job categories, turning away from traditional job categories defined primarily by geography and chronology and turning toward thematic job descriptions that include references to the history of sexuality and/or LGBTQ history.

Fifth, we can help promote the development of LGBTQ history and history of sexuality courses, as well as the use of LGBTQ history and history of sexuality readings, assignments, and units in other history courses. All of this has the potential to improve the status of LGBTQ history within the discipline of history, which could have enormously positive implications for the LGBTQ history job market.

Sixth, we can use our classrooms more effectively to teach the citizens of today and tomorrow about the values of education, the hard work and long hours involved in teaching and research, and the need to pour public resources into education. We also need to fight our governments and our administrators for increased funding for faculties and students. Until we do this, we will continue to struggle over a shrinking instead of an expanding pie.

And finally, we can recognize more fully, and here I admit that I rarely achieved this during my five-year search, that there is a politics to our everyday lives in academia, a politics with effects that we rarely can see or know in the short term. When I acknowledge that my road has been paved by the graduate school applications, seminar discussions, research papers, conference presentations, job applications, and job interviews of earlier LGBTQ historians, I begin to see that a graduate program that rejected me for admission might admit the next student who indicates that they want to study LGBTQ history. A professor who had doubts about LGBTQ history before reading my work may be more optimistic the next time a student chooses to work in this area. A classmate who learned about LGBTQ history because I talked about it in our graduate seminars may someday offer a lecture, supervise a research project, or hire a candidate working on this topic. A conference that rejected my proposal for a paper on LGBTQ history may not do so the next time a proposal in this area is submitted. A search committee that rejected me might give the next candidate in LGBTQ history more of a chance. And while I have been using LGBTQ history as my example, I hope that what I have written about the 
everyday politics of academia, the academic politics of identity, and the political economies of higher education has resonance for scholars working in other areas.

\section{Epilogue (2004)}

Returning to this essay almost five years after I wrote it is certainly a strange experience. Happily for me, some of the personal anger, angst, and anxiety that motivated it have dissipated, especially since I was tenured and promoted in 2001. And with tenure-track hires of LGBTQ historians in the past few years by history departments at Albright College, Brown University, Carleton University, Simon Fraser University, the University of Manitoba, the University of Minnesota, and Tulane University, I sometimes allow myself to feel cautiously optimistic. That said, I continue to hear numerous reports of homophobia and heterosexism experienced by others on the history job market; many highly talented, extremely bright, and very accomplished LGBTQ history scholars have continued to experience job market frustration and some have left the profession because of job market obstacles; and I now have witnessed, as a member of search committees and as a participant in discussions about hiring priorities and affirmative action policies, the operations of homophobia, heterosexism, transphobia, racism, and sexism and the intensity of resistance to efforts designed to promote nondiscriminatory standards of excellence in higher education. Moreover, the political climate in the United States and Canada continues to contribute to the underfunding of public colleges and universities (and the public sector more generally), which in turns limits the ability of these institutions to come up with creative and innovative solutions to the problems of inequality in the academic workplace. I remain convinced that organizing, mobilizing, and building strong antidiscrimination and affirmative action coalitions offer us our best hopes.

An earlier version of this essay was presented as a keynote address at the New Frontiers in Graduate History conference held at York University in March 1999. Jorge Olivares, who continues to teach me about crossing borders and who inhabits my best memories, dreams, and fantasies, deserves special thanks for helping me through the nightmares (and for reading multiple versions of this essay). I also thank my colleagues and students at York for ending some of my nightmares and the editors of Left History for their comments and suggestions. 


\section{Notes}

1 See Ralf Jurgens, "HIV Testing and Confidentiality: Final Report," Canadian HIV/AIDS Legal Network and Canadian AIDS Society, 1998, http://www.aidslaw.ca/Maincontent/issues/testing/08mandate2.html; AIDS Coalition to Unleash Power, "Mandatory HIV Testing of Applicants for Immigration," 2000, "Canada to Start Testing Immigrants for HIV," 4 December 2000, http://www.cnn.com/2000/Health/AIDS/12/04/canada.aids.reut/; David Garmaise, "Questions and Answers: Canada's Immigration Policies as They Affect People Living with HIV/AIDS," The Canadian HIV/AIDS Legal Network, March 2003. According to these sources, before the policy change announced in 2000 immigrants were tested for tuberculosis and syphilis; under the new policy immigrants would also be tested for HIV and hepatitis B. In adopting this policy, Canada joined 50 countries, including the United States, in requiring HIV tests for immigrants. The United States adopted a policy of mandatory HIV testing for immigrants in 1987.

2 For recent discussions of Boutilier, see William T. Reynolds, "The Immigration and Nationality Act and the Rights of Homosexual Aliens," Journal of Homosexuality 5, 1 2 (Fall 1979-Winter 1980): 79-87; Marc Bogatin, "The Immigration and Nationality Act and the Exclusion of Homosexual Aliens: Boutilier v. INS Revisited," Cardozo Law Review 2, 2 (Winter 1981): 359-396; Rachel A. Hexter, "Immigration - Naturalization," Suffolk Transnational Law Journal 6, 2 (Spring 1982): 383-394; Robert Poznanski, “The Propriety of Denying Entry to Homosexual Aliens: Examining the Public Health Service's Authority over Medical Exclusions," University of Michigan Journal of Law Reform 17 (Winter 1984): 331-359; Samuel M. Silvers, "The Exclusion and Expulsion of Homosexual Aliens," Columbia Human Rights Law Review 15, 2 (Spring 1984): 295332; Peter N. Fowler and Leonard Graff, "Gay Aliens and Immigration: Resolving the Conflict Between Hill and Longstaff," University of Dayton Law Review (1985): 621644; Philip Girard, "From Subversion to Liberation: Homosexuals and the Immigration Act, 1952-1977," Canadian Journal of Law and Society 2 (1987): 1-27; Richard Green, “'Give Me Your Tired, Your Poor, Your Huddled Masses' (of Heterosexuals): An Analysis of American and Canadian Immigration Policy," Anglo-American Law Review 16 (1987): 139-159; William N. Eskridge, Jr., "Gadamer/Statutory Interpretation," Columbia Law Review 90 (Apr. 1990): 609-681; Shannon Minter, "Sodomy and Public Morality Offenses Under US Immigration Law: Penalizing Lesbian and Gay Identity," Cornell International Law Journal 26 (1993): 771-817; William N. Eskridge, Jr., Dynamic Statutory Interpretation (Cambridge: Harvard Univ. Press, 1994), 48-80; Robert J. Foss, "The Demise of the Homosexual Exclusion: New Possibilities for Gay and Lesbian Immigration," Harvard Civil Rights-Civil Liberties Law Review 29, 2 (Spring 1994; dated Spring 1993 on the internet): 439-475; William B. Turner, "Lesbian/Gay Rights and Immigration Policy: Lobbying to End the Medical Model," Journal of Policy History 7, 2 (1995): 208-225; Eithne Luibheid, “'Obvious Homosexuals And Homosexuals Who Cover Up: Lesbian and Gay Exclusion in US Immigration," Radical America 26, 2 (Apr.-Jun. 1992, published Oct. 1996): 33-40; William N. Eskridge, "Challenging the Apartheid of the Closet: Establishing Conditions for Lesbian and Gay Intimacy, Nomos, and Citizenship, 1961-1981," Hofstra Law Review 25 (Spring 1997): 817-960; William N. Eskridge, Jr., and Nan D. Hunter, 
Sexuality, Gender, and the Law (Westbury: Foundation, 1997), 175-189; Eithne Luibheid, “'Looking Like A Lesbian': The Organization of Sexual Monitoring at the United States-Mexican Border," Journal of the History of Sexuality 8, 3 (Jan. 1998): 477-506; William N. Eskridge, Jr., Gaylaw: Challenging the Apartheid of the Closet (Cambridge: Harvard Univ. Press, 1999), 35-36, 69-70, 132-134, 383-384; Barney Frank, "American Immigration Law: A Case Study in the Effective Use of the Political Process," in Creating Change: Sexuality, Public Policy, and Civil Rights, ed. John D'Emilio, William B. Turner, Urvashi Vaid (New York: St. Martin's Press, 2000), 208235; Joyce Murdoch and Deb Price, Courting Justice: Gay Men and Lesbians v. the Supreme Court (New York: Basic, 2001), 103-134; Eithne Luibheid, Entry Denied: Controlling Sexuality at the Border (Minneapolis: University of Minnesota Press, 2002), 77-101; Margot Canaday, “'Who Is A Homosexual?': The Consolidation of Sexual Identities in Mid-Twentieth-Century American Immigration Law," Law and Social Inquiry 28, 2 (Spring 2003): 351-386; Marc Stein, "Forgetting and Remembering a Deported Alien," History News Network, 3 November 2003, http://hnn.us/articles $/ 1769 . \mathrm{html}$.

${ }^{3}$ Earlier history dissertations primarily or partially focusing on US lesbian/gay topics include Salvatore John Licata, "Gay Power: A History of the American Gay Movement, 1908-1974," University of Southern California, History, 1978; Ramón A. Gutiérrez, "Marriage, Sex and the Family: Social Change in Colonial New Mexico, 1690-1846," University of Wisconsin, Madison, History, 1980; John D'Emilio, "Out of the Shadows: The Homosexual Emancipation Movement in the United States," Columbia University, History, 1982; George Chauncey, "Gay New York: Urban Culture and the Making of the Gay Male World, 1890-1940," Yale University, History, 1989; Susan Cahn, "Coming On Strong: Gender and Sexuality in Women's Sport," University of Minnesota, History, 1990; Sharon Ullman, "Broken Silences: Sex and Culture in Turn of the Century America," University of California, Berkeley, History, 1990; Kevin F. White, "The Flapper's Boyfriend: The Revolution in Morals and the Emergence of Modern American Male Sexuality, 1910-1930," Ohio State University, History, 1990; Will Roscoe, "The Zuni Man-Woman: An Ethnohistorical Study of a Third Gender Role," University of California at Santa Cruz, History of Consciousness, 1991; Lisa Duggan, "The Trials of Alice Mitchell: Sex, Science, and Sensationalism in Turn of the Century America," University of Pennsylvania, History, 1992; Leisa Meyer, "Creating G. I. Jane: The Women's Army Corps During World War II," University of Wisconsin at Madison, History, 1993; Kevin J. Mumford, "From Vice to Vogue: Black/White Sexuality and the 1920s," Stanford University, History 1993. For a more comprehensive and up-to-date listing of related history dissertations, see: http://www.usc.edu/isd/ archives/clh/dissertations.html.

${ }^{4}$ For other accounts of homophobia and heterosexism in the historical profession, see Peter Boag, "Foreword," John Gerassi, The Boys of Boise: Furor, Vice, and Folly in an American City (1966; Seattle: University of Washington Press, 2001), vii-xvii; George Chauncey, "The Queer History and Politics of Lesbian and Gay Studies," in Queer Frontiers: Millennial Geographies, Genders, and Generations, ed. Joseph A. Boone et al (Madison: University of Wisconsin Press, 2000), 298-315; John D'Emilio, Making Trouble: Essays on Gay History, Politics, and the University (New York: Routledge, 1992); John D'Emilio, The World Turned: Essays on Gay History, Politics, and Culture 
(Durham: Duke University Press, 2002); Martin Duberman, About Time: Exploring the Gay Past (New York: Gay Presses of New York, 1991); Martin Duberman, Cures: $A$ Gay Man's Odyssey (New York: Dutton, 1991); Martin Duberman, Left Out: The Politics of Exclusion (New York: Basic, 1999); Martin Duberman, Midlife Queer: Autobiography of a Decade, 1971-1981 (New York: Scribner, 1996); Lisa Duggan and Nan D. Hunter, Sex Wars: Sexual Dissent and Political Culture (New York: Routledge, 1995). On homophobia and heterosexism in academia more generally, see The Gay Academic, ed. Louie Crew (Palm Springs: ETC, 1978); Toni A. H. McNaron, Poisoned Ivy: Lesbian and Gay Academics Confronting Homophobia (Philadelphia: Temple University Press, 1997).

${ }^{5}$ Here and elsewhere in this essay I report information that I received, directly or indirectly, from members of search committees and hiring departments. In most cases I asked for and received permission to share these accounts anonymously. While members of search committees and hiring departments often operate with implicit or explicit expectations of confidentiality, these expectations generally regulate those who are doing the hiring, not those who are being interviewed. I cannot guarantee the accuracy of all of this information. It is certainly possible that I received inaccurate or partial information. That said, I do not include here information that I received that seemed untrustworthy or unreliable and most of the information reported here came from multiple sources. Also, insofar as this essay describes my subjective experiences on the job market, in some respects the question of whether the information I received was accurate is less important than the fact that $I$ received this information.

6 "Robbing the Cradle," Lingua Franca, May 1995, 20-22.

7 See "Committee on Lesbian and Gay History Survey on LGBTQ History Careers," Perspectives, May 2001, 29-31. For a longer and more detailed version of this report, see http://www.usc.edu/isd/archives/clgh/reports.html. See also Anna Clark, "Report on the Survey of Lesbian and Gay Historians by the Committee on Women Historians," 31 January 1993; Committee on Women Historians, "Report on the Lesbian and Gay Historians Survey," Perspectives, April 1993, 13-15; Verta Taylor and Nicole C. Raeburn, "Identity Politics as High-Risk Activism: Career Consequences for Lesbian, Gay and Bisexual Sociologists," Social Problems 42, 2 (May 1995): 252-273; Committee on the Status of Lesbians and Gays in the Profession of the American Political Science Association, "Report on the Status of Lesbians and Gays in the Political Science Profession," PS: Political Science and Politics 28, 3 (September 1995): 561-574; Commission on Lesbian, Gay, Bisexual, and Transgendered Issues in Anthropology, Final Report, November 1999, Committee on the Status of Lesbian, Gay, Bisexual, and Transgendered Persons in the Discipline, "Report on the Status of Lesbian, Gay, Bisexual, and Transgendered Persons in Sociology," 16 July 2002, http:/www.asanet.org/governance/GLBTrpt.html. 